\title{
Could Stem Cells Drive Research and Entrepreneurship in Egypt?
}

\section{Montaser LM*}

Professor of Clinical Pathology, Menoufia University, Egypt

*Corresponding author: Laila Mahmoud Montaser, Professor of Clinical Pathology, Chair, Stem Cell, Regenerative Medicine, Nanotechnology and Tissue Engineering (SRNT) Research Group, Faculty of Medicine, Menoufia University, Egypt, Email: lailamontaser@gmail.com

\section{Editorial}

Volume 5 Issue 2

Received Date: October 19, 2021

Published Date: October 28, 2021

DOI: $10.23880 /$ jes- 16000155

\section{Editorial}

I supposed of finding what I would write about in a new Editorial as I have several modern subjects to present about fantastic gigantic stem cell the sacred cup of regenerative medicine and the medical innovation of the 21st Century; then fate made it simple by unexpectedly receiving an honorable calling to be nominated for Global Entrepreneurship Award for Excellence. So, I have confirmed to write this article beacon the narrative from the onset behind this request. Thanks to the organizer of this honorable award to recollect me; this has stimulated me to remember what happened at that date and to talk now about the Unknown Soldier who presented the secret sauce that launched the pioneer initiative to implement entrepreneurship education in Egypt that is applied at present not only in Egypt but also in all the Arab World and North Africa.
This inspired the idea of the theme of this Editorial by incorporating stem cells with entrepreneurship; where I suggested two titles to select one of them, the 1st was "Who is the Unknown Soldier that Launched the Pioneer Initiative to Implement Entrepreneurship Education in Egypt? ", while the 2nd was under the title "Could Stem Cells Drive Research and Entrepreneurship in Egypt?". It is well known that Prof. Laila Montaser is a Clinical Pathology scientist who had already established herself as a leader in the kingdom of stem cell science. More than one decade prior, Montaser and colleagues isolated mesenchymal stem cells (MSCs) from humans and implemented Nano-biomaterial-based cell culture to apply in experimental animal models with many diseases [1-5]. Schematic of MSCs isolation is symbolized in Figure 1.

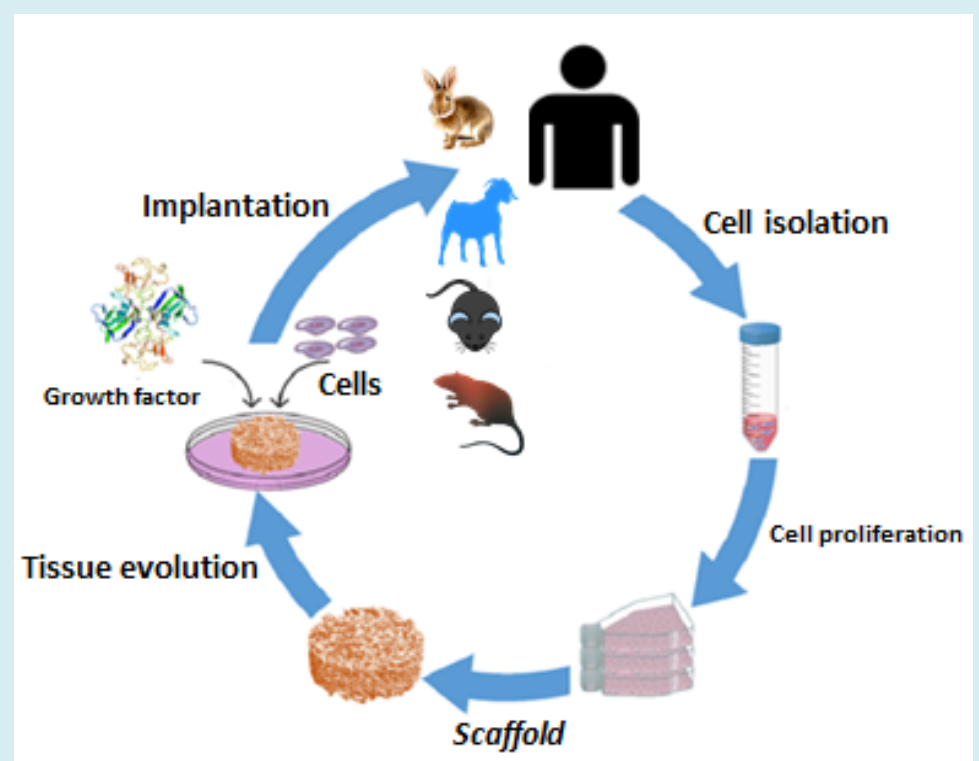

Figure 1: Schematic of the isolation of mesenchymal stem cells from humans and implement of Nano-biomaterial-based cell culture to apply in experimental animal models with many diseases. 


\section{Journal of Embryology \& Stem Cell Research}

The first move was to remember the narrative that had an unforgettable impact in my life. It's really the socalled small narratives or little "periods" that brings out the secret gold that I'm researching for. So I liberate the "period" from my life that forms the leading influence and in particular lookout why it made that a key and pioneer effect. At the beginning of Millennium 2021, when I was returning from abroad, I presented a full protocol about the idea of establishing a stem cell center at the Faculty of Medicine, Menoufia University, but the response was negative. At that early date, if the response had been positive, this center would have been the premier in Egypt on this high level. In 2009 a research lab was established in the Clinical Pathology Department at Menoufia Faculty of Medicine. Stem cell, regenerative medicine, nanotechnology and tissue engineering (SRNT) research group was started by a group of scientists at Menoufia University in Egypt leader by Prof. Laila Montaser Former: Chair, Founder leader of Clinical Pathology Department; as the Chair of the group (Inaugural holder of the SRNT Chair). SRNT research group is involved in treatment development and is investing in an animal facility to conduct preclinical efficacy studies for cell-based therapies.

Mukherjee S, et al. [6] stated that Stem cells are undifferentiated cells that can itself-renovate and distinguish into varied kinds of adult and effective cells whilst preserving their premier personality. This deep prospect of stem cells has been comprehensively researched for its importance in regenerative medicine and has put the basis for cell-based therapies. Regenerative medicine is quickly advancing in healthcare with the hope of reform and reestablishment of certain organs or tissue damages or chronic disease cases where the body's regenerative procedure is not adequate to recover. My opinion agreed with that of Cauwenberghe CV [7] who stated that chiefly, almost all strategies are joined to imitate organ and tissue styles through scaffold manufacturing, 3D bio printing, and oneself-installation. In a similar way, other tactics adopt the incorporation of inoculations with the steward by vascularization and innervation with a view to supply wider and extra precise implementation.

My view about adult stem cells harmonizes with Pareira WC [8] from India who reported that the stem cell research market in the world has grown-up exponentially during the previous decades. Now, my final target as a stem cell scientist is to be capable of structure tissues or organs that can substitute damaged or maladies tissues in the human body. This notion which leads to the prosperity of mature tissues has made adult stem cells the center of intensive research, asked to cure a set of human illnesses. In the clinical script, stem cells are anticipated to be transplanted inside the injured area and then develop to a fresh, healthful tissue. Also, my opinion about stem cell research in Egypt coincides with Anand A [9] from India explaining that the recognized features comprised the vast number of people in India and great series of diseases on which research might be managed; the basically relatively little cost of performing stem cell research in India.

Lorenzsonn E [10] advertised in November 14, 2018 in the Capital Times that high spots stem cell research milestones, defies and outlook probabilities on the 20th anniversary of stem cell research at UW-Madison in "Small miracles: Stem cells drive research and entrepreneurship in Madison." The paper reports the act of Waisman Center researcher Su-Chun Zhang, a major in evolving stem cellsoriginated from neural cells.

SRNT research group is involved in treatment development [11-13] and is investing in an animal facility to conduct preclinical efficacy studies for cell-based therapies [14-21]. The SRNT business paradigm is to harness both scientists and clinicians in evolving technology while matching with healthcare distribution suits. The SRNT research group has begun later on a Nano-biomaterialbased cell culture. Advanced technologies are authorizing regenerative medicine via the presentation of novel, extra precise, comfortable-to-utilize agents. So, one of the utmost pertinent inventions is bound to the proliferation of autologous cells for transplantation. The regenerative medicine market is accelerated to a great degree by the emergence of stem cell technology. Sure, stem cells are catching great attentiveness in the regenerative medicine scope.

This technology calls for the development of automatic watching and alarm methods to guard safely autologous cell transplants, led by companies.

The beginning of the story of the Unknown Soldier who presented the secret sauce that launched the initiative to implement entrepreneurship education in Egypt by my proposal for establishment of the Entrepreneurship Education Center at Menoufia University. In the 20I0; I answered many invitations to contribute oral presentations on development of education, entrepreneurship and learning technology to many esteemed conferences: Portoroz, Slovenia; Madrid, Valencia, Barcelona, Spain; Beirut, Lebanon; Abu Dhabi, UAE; and Florence, Italy inspired me a series of papers published in their proceedings [22-30]. So my interest, enthusiasm and eagerness in Entrepreneurship started at that time. In the second half of the 2010 year, while I was preparing to present oral speeches and articles on educational development, I found the treasure called Entrepreneurship which is the induction or extraction of worth by an act of being an entrepreneur, or "the possessor 


\section{Journal of Embryology \& Stem Cell Research}

or director of a commerce project who, by hazard and inventiveness, tries to do revenues". The other thesaurus was entrepreneurship education which endeavors to supply pupils with the information, skillfulness and stimulus to promote entrepreneurial prosperity in a set of scopes.

This inspired me to the idea of a national project to launch a new strategy by integration of new education method in the educational system in Egypt focused on the preparation of youth to meet the requirements of the labor market and develop a plan to implement the education needs associated with the labor market. In December of a 2010 year, I presented the idea of establishing an entrepreneurship center at Menoufia University to the university leader; where I showed a national project to launch a new strategy by integration of new education method in the educational system in Egypt focuses on the preparation of youth to meet the requirements of the labor market and develop a plan to implement the education needs associated with the labor market. He liked the idea, encouraged and asked me to start implementing it.

I immediately proceeded to meet the professors who would help me in the implementation and presented them with the work protocol about my proposal of a national project "to integrate entrepreneurship education into the educational system in Egypt". They were very excited, and one of them was the former Vice President of the University for Graduate Studies and Research, who advised me to document my project as an intellectual property (IP) for fear of being stolen; so I fulfilled registration of my IP immediately on the 18th of April 2011 under the No. 91. I visited the Entrepreneurship Center at the University of Alexandria and learned from the head of the center, that the wonderful and successful project of the red double-decker bus that roams the coast of the beautiful city Alexandria; on the Corniche from the Montazah Palace area in the east to the area near Ras El-Tin Palace in the west and back, is a wonderful idea for a group of his students who became business pioneers (entrepreneurs).

On 25 January 2011, violent political events broke out necessitating the closure of schools and universities and the suspension of studies for a few months. I went to present my project to the Minister of Education, who welcomed me in his office; he referred the matter to the Undersecretary of the Ministry, and then hurried to the cabinet meeting. I met the Minister of Higher Education, who was a professor of the Faculty of Medicine, who expressed great admiration for my idea and said that he is always saying that graduates of medical schools are the greatest thinkers and most genius in the world. Then the university leader changed, the response to the project became negative and he advised me as a medical professional to leave the idea of entrepreneurship education and continue with my stem cell research.

After I successfully delivered my oral speech at the Abu Dhabi conference in January 2012 titled "Promoting Islamic Entrepreneurship in the Arab World", a prominent Malaysian professor was sitting in the front row with great interest in my presentation, and highly praised my lecture and its excellent format. Then he asked me why you did not implement these wonderful ideas in Egypt that you presented to us about developing education by applying entrepreneurship education. I replied that I had met the Ministers of Education and Higher Education in Egypt in 2011, then after a short period all the ministers were changed several times and nothing was done in this regard.

On Nov 2010 at a conference in Madrid, Spain, and after I successfully presented my oral presentation about "Entrepreneurial Education \& Globalization in Middle East \& Mediterranean Region", I was presented to a university professor to work at a university in the Arabian Gulf as an expert in entrepreneurship, so I apologized to her that I am a professor at the Faculty of Medicine in Egypt and have very important research in stem cells and their application in regenerative medicine as a treatment for some diseases, which I follow closely myself. Egypt's investment in stem cell research could be forced by its economic outgrowth and view to gain world leadership in bio curatives. Ready to conquer the defies the moment that is symbolized by the lack of association of IP lawyers, clinician-scientists and project financiers, the clef parts in biotechnology entrepreneurship, so that the economic advance is sustainable.

The marks of avoidance of brain drain that one time impacted worth ingenuity are presently appealing obvious. I am actually suffering from brain drain abroad of most of my eminent SRNT group researchers. However, there are scarce academic issues such as power styles, shortage of fulfillment based energizers and seniority through worth tenet, just a consented bit of Egyptian academics that prospect to check so that the institutional and faculty favor orders are excessive and reacting to innovation systems. The health and science leaders in Egypt understand that Egypt should depend on its own capability for innovation rather than rely on a multinational corporation (MNC) outsourced pattern.

This will need extra violent politics modulations in the mode that simplify scientific mood, productivity and entrepreneurship. Egypt has an unparalleled collection of old information basis and up-to-date technology in order to invade inside science work. The classical arrangement of realizing awareness in Egypt depended on free education. The notion of science entrepreneurship has thus ever 


\section{Journal of Embryology \& Stem Cell Research}

called the political intellectuals, policy producers or the biomedical scientists till recently. Increment, plurality of the research in Egypt has persisted to be favored by solitary general supplies, in order that the licensing and defense of patents has continued under government leadership and commercialization of scientific ventures needing routine authorizations. The lack of special patronage research entities has contributed to deficiency of sensibility about the business expectancies of the scientific thoughts.

Now, the publicity originated by stem cell research can be favorably interpreted into ingenuity stem cell centers wherever research and clinical trials can proceed together and by not only serving a very big portion of irremediable degenerative diseases but also by catching premier grade brains into the sphere. The connectedness between development in research and rationalization of therapy prices and its growth through entrepreneurship paradigms required to be lighted by science leaders. A number of companies have brought into the market beginning with the presentation of culture medium and reagents for regenerative medicine enforcement, to then mend across the evolution of new cell-based therapies ruled on stem cells. With the boost in the number of regenerative medicine centers, the stem cell market is also anticipated to grow in the future. Montaser and her fellow SRNT researchers are working on bioengineering the patches of tissues created from human stem cells and testing them out on animal models, which could pave the way for human trials in the near future.

Inventions that minimize operation prices have before occurred in the stem cell scope. Our target is to originate our price-effective cell and tissue cultivation and to pill technicalities that can lower the charge for the Egyptian client. This should not be achieved at the expense of advancing reign renovation frameworks and treasure troves which will positively come from investments in basal research. As technology develops, therapies may be extra inexpensive and both the endeavor of special entrepreneurship and the government will quicken the enterprise in this matter. During 2019-2020 Montaser and SRNT team participated in some research projects but hampered by the negativity/ routine/ birocratic and/or then now the crisis of COVID-19 pandemic: i)Joint proposal project 2019 in the framework of the Cooperation between Egypt and other foreign country targeted to originate an amended manner of 3D printing to create in vitro a specific organ tissue, ii)Endorsement of Prof. Laila Montaser by Menoufia University to the Ministry of Higher Education for a mission: Proposed topic: "Biotechnology Incubator Program 2019", iii)KUDOS Pro has curated a selection of the latest research from Prof. Laila Montaser, hand-picked as a featured Project. Montaser project endorsed by Kudos 2020 titled "Nanotechnology drives innovation to cure COVID-19 through stem cells".
Despite the hurdles caused by negativity, bureaucracy and/or the catastrophe of the Covid-19 pandemic that has swept the world and since its inception has caused a global closure of schools, universities and laboratories and made us stay home without work. We had to think outside the box because we were locked in the house, but there was a glimmer of hope because our minds were free. I thought about fighting the covid-19 pandemic by writing a number of articles published in international journals to present my views and opinions. I presented innovative ideas for possible treating covid-19 using plasma, stem cells or stem cells with the application of nanotechnology. Since the publication of the first paper, which was still in print, I have received many invitations, amounting to over 100 , most of them to speak as a keynote speaker on COVID-19 at global online conferences broadcasted from four continents. I selected only about a third of these invitations. In the status of COVID-19, government collectives in different countries, research institutes, and numerous biotech and pharmaceutical companies are concentrating on efficient and quick technologies for the prompt diagnosis and possible therapy of COVID-19.

In 2020-2021, according to Montaser four perspective articles [31-34] published in scientific peer-reviewed journals, the 1 st one hypothesized that plasma from recovered patients proposal as a therapy for new COVID-19 patients while the other three supposed that blood derived mesenchymal stem cells (MSCs) generated from the critically ill novel COVID-19 patient itself (autologous) suggested as a treatment for him. So, Montaser point of view could mark an up-to-date medicinal strategy. I gained Seventeen respectable Certificates of Appreciation from successfully presenting a series of thirty three esteemed conferences online (51.5\%) through the era of COVID-19. The Certificates were presented in appreciation of an outstanding University Professor for her devoted and untiring endeavors to educate scientific society and public awareness on the COVID-19 pandemic and her diverse perspectives, notions, and viewpoints provided extra innovation and best resolutions.

Most of these online conferences and certificates of appreciation in my talks about them were documented in two editorial articles published in two international journals in June and Aug 2021 respectively [35,36], with the exception of the recent three conferences* which were presented in September 2021 and resulted in my being honored with new four Certificates of Merit, three for the brilliant oral presentations I have given successfully and for the exceptional effort I has made, while the fourth testimonial was in gratitude for my ably presiding over the main session of the 4th International Conference on Biomaterials and Nano materials Sept. $29^{\text {th }}, 2021$, which was broadcasted from Edinburg, Scotland, England. 


\section{Journal of Embryology \& Stem Cell Research}

In conclusion, we're merely at the beginning of this epoch of regenerative medicine. There's yet too frequently to be achieved. Science and innovation prospers when everybody has the liberty to consider. The rapid advancements in the area of stem cell research have the potential to make Egypt an international capital of stem cell research therapy. Egypt has the capability to share in an extra recent stem cell research due to the robust spread of pharmaceutical and biotechnology segments. As technology develops, therapies may be extra inexpensive and both the endeavor of special entrepreneurship and the government will quicken the enterprise in this matter. Only time will tell if stem cell treatments, as they evolve, will turn into a broadly obtainable cure choice for Egyptians. Twenty years ago, at the beginning of the millennium 2021, if the initiative of Montaser had been implemented at that early time to establish a high-level advanced center for stem cells and regenerative medicine at the Menoufia Faculty of Medicine, Menoufia University would have been the first of its kind at that time, not only in Egypt but in the Arab world and North Africa. Also, in the year 2011, if Montaser's initiative, her innovative and pioneering idea, was implemented to establish an entrepreneurship center at Menoufia University to introduce entrepreneurship education in Egypt, Menoufia University would have become, since then, a beacon of science and innovation in the heart of Egypt, whose light shines not only in Egypt alone but also in the whole Arab world and perhaps globally. Lastly I can advertise, Prof. Laila Montaser is the unknown soldier who launched an initiative ten years ago, the idea of introducing entrepreneurship education into the educational system in Egypt, which has only begun to be implemented now, and the prove of her story, the series of articles that she launched and presented herself at international conferences abroad on the development of education and entrepreneurship was published all of them in the book of these conferences and online at the time, in addition to her intellectual property No. 91, dated April 2011.

\section{References}

1. Montaser LM, El Azab DS, Tawfeek GA, Saied SA (2019) The Role of stem cells in a model of hepatic regeneration. Int J Lab Hematol 41(S2): 122-122.

2. Montaser LM, El Azab DS, Tawfeek GA, Saied SA (2019) Applications of bone marrow-derived cells in acute liver disease. Menoufia Med J 32(4): 1496-1500.

3. Montaser LM, Fawzy SM (2019) Novelties in Cartilage Tissue Regeneration using Nano Scaffolds. Int J Mater Sci Res 2: 22-22.

4. Montaser LM (2020) A Feminist Scientist Shouts Conveying I Am Here. J Embryol Stem Cell Res 4(1): 000134.
5. Montaser LM, El Azab DS, Kotb EAZ (2020) Mesenchymal stem cell applications on the chronic liver disease. Menoufia Med J 33(1): 236-242.

6. Mukherjee S, Yadav G, Kumar R (2021) Recent trends in stem cell-based therapies and applications of artificial intelligence in regenerative medicine. World J Stem Cells 13(6): 521-541.

7. Cauwenberghe CV (2017) Technology and business trends in regenerative medicine. Adv Tissue Eng Regen Med Open Access 3(2): 362-366.

8. Pareira WC (2010) Stem cell entrepreneurship-trends and advances-II. Ann Neurosci 17(4): 154-157.

9. Anand A (2010) Stem cell entrepreneurship in India: trends and advances-I. Ann Neurosci 17(3): 106-109.

10. Lorenzsonn E (2018) Small miracle: Stem cells drive research and entrepreneurship in Madison. University of Wisconsin-Madison.

11. Montaser LM (2016) Regenerative Medicine and Tissue Engineering-Driven Innovation of Medical Science and Technology. Adv Tissue Eng Regen Med Open Access 1(1): 1-2.

12. Montaser LM, Eid TA, Helwa MA, Mesregah MK (2017) Application of platelet-rich plasma preparation rich in growth factors in knee osteoarthritis. Menoufia Med J 30(1): 139-146.

13. Montaser LM (2018) Editorial: Outcomes of technology's epic success stories in the field of regenerative medicine and tissue engineering. Adv Tissue Eng Regen Med 4(4): 100-101.

14. Montaser LM, Fawzy SM (2020) Innovative patterning of electrospinning fabrication Nano scaffolds with cell culturing for liver tissue engineering. Proc. of the SPIE 11467.

15. Montaser LM, Fawzy SM (2019) Novelties in Cartilage Tissue Regeneration using Nano Scaffolds. Presented at: 3rd International Conference on Materials Science and Research (ICMSR), 28-29 Nov 2019, Kuala Lumpur, Malaysia. Int J Mater Sci Res 2: 23-23.

16. Montaser LM, Fawzy SM (2018) Nanotechnology for articular cartilage regeneration. Presented at: International Conference on Nanotechnology and Nano engineering, July 16-18, 2018, Paris, France. J Nanomater Mol Nanotechnol 7: 71.

17. Montaser LM (2018) Hepatic Tissue Engineering and Regenerative Medicine. Presented at: World Biotechnology Congress July 16-17, 2018 Berlin, Germany. J Med Biotechnol 2: 16. 


\section{Journal of Embryology \& Stem Cell Research}

18. Montaser LM (2017) Usage of Stem Cell, Regenerative Medicine, Nanotechnology and Tissue Engineering Science Education to Improve Stem Cell and NanoScience Literacy. Adv Tissue Eng Regen Med 2(2): 168169.

19. Montaser LM, Abbassy HA, Fawzy SM (2016) Articular cartilage tissue engineering with plasma-rich in growth factors and stem cells with Nano scaffolds. SPIE Proceedings 9930.

20. Montaser LM, Fawzy SM (2015) NANO scaffolds and stem cell therapy in liver tissue engineering. SPIE Proceedings 9550.

21. Montaser LM, Fawzy SM (2014) Promising cell therapy achieves improvement outcomes. Experimental Hematology-J for Hematology Stem Cell Biology and Transplantation 42(8): S53.

22. Montaser LM, Mortada MM, Fawzy SM (2010) Fostering Entrepreneurial Education in Middle East \& Mediterranean Region. Proceedings of the 3rd EMUNI Conference on Higher Education \& Research (International Conference of Entrepreneurial Learning \& the Role of Universities), Portoroz, Slovenia, pp: 218225.

23. Montaser LM, Mortada MM, Fawzy SM (2010) Entrepreneurial Education \& Globalization in Middle East \& Mediterranean Region. Proceedings of ICERI Conference, (International Conference of Education, Research \& Innovation), Madrid, Spain, pp: 7022-7031.

24. Montaser LM, Mortada MM, Fawzy SM (2011) Development of Entrepreneurial Education in Middle East \& Mediterranean region. Proceedings of the INTED Conference (International Technology, Education \& Development Conference), Valencia, Spain, pp: 16811687.

25. Montaser LM, Mortada MM, Fawzy SM (2011) Fostering Innovation Entrepreneurship through higher Education System in Middle East and Mediterranean Region. Proceedings of the 3rd EMUNI Research Souk on Innovation \& Employability-the Universities Challenge, Beirut Arab University, Beirut, Lebanon, pp: 418-425.

26. Montaser LM, Mortada MM, Fawzy SM (2011) Fostering E-Learning in Egypt and Arab World. Proceedings of the 3rd International Conference on Education and New Learning Technologies (edulearn11), Barcelona, Spain, pp: 4964-4971.

27. Montaser LM, Mortada MM, Fawzy SM (2012) Promotion of Islamic Entrepreneurship in the Arab world. Proceedings of 2nd Global Islamic Marketing Conference
(GIMCO 2), Abu Dhabi, UAE, pp: 276-281.

28. Montaser LM, Mortada MM, Fawzy SM (2012) Impact of Technology on the Future of Education. Proceedings of the International Conference on Education \& New learning Technologies (EDULEARN12), Barcelona, Spain, pp: 3881-3887.

29. Montaser LM, Mortada MM, Fawzy SM (2012) The Role of Education in Development. Proceedings of the International Conference on Education \& New learning Technologies (EDULEARN12), Barcelona, Spain, pp: 3901-3907.

30. Montaser LM (2013) Use of E-Learning Technology in Medical Science Education. Presented at: International Workshop "Science Education \& Guidance in Schools: The way forward", Florence, Italy. Proc. of the Workshop, pp: 1-7.

31. Montaser LM (2020) A Therapeutic Approach from Lab to Clinic in the Domain of the Disease Caused by the Novel Coronavirus from the Perspective of an Egyptian Scientist. CPQ Medicine 8(6): 1-7.

32. Montaser LM (2020) Could putting the mesenchymal stem cells technology into practice be an optimistic therapy for the critically ill COVID 19?. J Chem Edu Res Prac 4(2): 1-4.

33. Montaser LM (2020) Innovative outlook for containing COVID-19. World J Pharmacol Toxicol 3(2): 1-2.

34. Montaser LM (2021) In Continuously Battling COVID-19 with Innovative Perspectives. Reg biol Med 3(2): 1-5.

35. Montaser LM (2021) Ideal behavioral response to lockdown amidst COVID-19 crisis. Adv Tissue Eng Regen Med Open Access 7(1): 35-38.

36. Montaser LM (2021) Unprecedented Year Story to Success. J Reg Med Biol Res 2(2):1-4.

\section{Footnotes}

1. Montaser LM (2021) Keynote speaker awarded a Certificate of Appreciation: 3D printing technology as the digital transformation innovation for digital health sustainable strategies. 1st Int. Conf. on Digital Transformation, Dar es Salam, Tanzania.

2. Montaser LM (2021) Invited speech; presented video with Chinese translation awarded a Certificate of Appreciation: Application of 3D bioprinting for tissue engineering amidst the COVID-19 crisis. BIT'S $14^{\text {th }}$ Regenerative Medicine \& Stem Cells 2021, Dalian, China. Proceedings of Bio-Pharma Industry Congress 2021 


\section{Journal of Embryology \& Stem Cell Research}

Sept, Dalian, China, pp: 251-251.

3. Montaser LM (2021) Keynote speaker \& Chair of Plenary Session awarded two Certificates of Appreciation: Emerging 3D printing biomaterials in tissue engineering. Presented at: 4th International Conference on Biomaterials and Nano materials scheduled on Sept 29th, 2021 at Edinburg, Scotland.

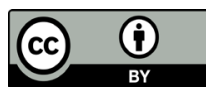

